\title{
Effect of Different Cultural Media on Growth of Sclerotium rolfsii sacc. causing Root Rot of Chilli
}

\author{
T.S. Archana*, Pankaj B. Deore, S.D. Jagtap and B.S. Patil \\ Department Plant Pathology, College of Agriculture, Dhule- 424004 \\ Mahatma Phule Krishi Vidyapeeth, Rahuri (Maharashtra, India) \\ *Corresponding author
}

\begin{abstract}
A B S T R A C T
Keywords

Sclerotium rolfsii,

Host extract agar medium, Potato dextrose agar

Article Info

Accepted:

22 January 2019

Available Online:

10 February 2019

Chilli is grown in many states in India as a valuable trade crop. Chilli accounts for $20-30 \%$ of total Indian spices exports valuing approx Rs. 400-500 cores. Nine cultural media Potato dextrose agar, Host extract agar (Chilli), Oat meal agar, Carrot agar, Plane agar, Richards agar, Czapeks agar, Elliots agar, Saboroud's agar were analyzed for in vitro mycelial growth of Sclerotium rolfsii. The cultural characteristics indicated that the excellent growth and sclerotia formation were observed on different semi-synthetic media viz., Potato dextrose agar and Host extract agar medium (Chilli) followed by Oat meal agar, Saboround's agar and Richard's agar.

\section{Introduction}

Sclerotium rolfsii is widely distributed in tropics, subtropics and also in warmer parts of temperate zone of the world. In India, it is wide spread in almost all the states and causing economic losses in many crops. The numerous reports from tropical and subtropical areas of the world, coupled with the large number of hosts attacked by it indicate that, economic losses are substantial every year due to infection of Sclerotium rolfsii (Aycock, 1966). Sclerotium rolfsii is a soil inhabitant, non-target, polyphagous and an ubiquitous facultative parasite. It has wide

host range infecting particularly solanaceous crops. It is documented that, fungus infects more than 500 plant species (Rupe, 1999).

Among the soil borne diseases, root rot caused by Sclerotium rolfsii is gaining a serious status. This disease also referred as Sclerotium blight, Sclerotium wilt, Southern blight, Southern stem rot and white mold. This fungus is distributed throughout the world and is particularly prevalent in warmer climate and significant yield losses can be seen in monoculture or short rotation with other crops which are susceptible to this pathogen (Aken and Dashiell, 1991).
\end{abstract}


Materials and Methods

\section{Isolation of Sclerotium rolfsii}

Isolation of Sclerotium rolfsii was carried out from diseases chilli plant collected from Khandesh redion.

\section{Cultural studies}

The cultural characters of the pathogen were studied on the following solid media viz.,

\section{Potato dextrose agar}

Potato $=200 \mathrm{~g}$

Dextrose $=20 \mathrm{~g}$

Agar $=20 \mathrm{~g}$

Distilled water $=1000 \mathrm{ml}$

\section{Host extract agar (chilli)}

Healthy chilli leaves $=200 \mathrm{~g}$

Dextrose $=20 \mathrm{~g}$

Agar-agar $=20 \mathrm{~g}$

Distilled water $=1000 \mathrm{ml}$

\section{Oat meal agar}

Oat meal $=30 \mathrm{~g}$

Agar-agar $=20 \mathrm{~g}$

Distilled water $=1000 \mathrm{ml}$

\section{Carrot agar}

Carrot $=200 \mathrm{~g}$

Dextrose $=20 \mathrm{~g}$

Agar-agar $=20 \mathrm{~g}$

Distilled water $=1000 \mathrm{ml}$

\section{Plane agar}

Dextose $=20 \mathrm{~g}$

Agar-agar $=20 \mathrm{~g}$

Distilled water $=1000 \mathrm{ml}$

\section{Synthetic media}

\section{Richard's agar}

Potassium nitrate $\left(\mathrm{KNO}_{3}\right)=10 \mathrm{~g}$ Potassium monobasic phosphate $\left(\mathrm{KH}_{2} \mathrm{PO}_{4}\right)=5 \mathrm{~g}$ Magnesium sulphate $\left(\mathrm{Mg} \mathrm{SO}_{4} .7 \mathrm{H}_{2} \mathrm{O}\right)=2.5 \mathrm{~g}$, Ferric chloride $\left(\mathrm{Fecl}_{3} .6 \mathrm{H}_{2} \mathrm{O}\right)=0.02 \mathrm{~g}$

Sucrose $\left(\mathrm{C}_{12} \mathrm{H}_{22} \mathrm{O}_{11}\right)=50 \mathrm{~g}$

Agar-agar $=15 \mathrm{~g}$

Distilled water $=1000 \mathrm{ml}$.

\section{Czapek's Dox agar}

Sodium nitrate $\left(\mathrm{NaNO}_{3}\right)=3 \mathrm{~g}$

Potassium dihydrogen phosphate (K2HPO4)

$=1 \mathrm{~g}$

Magnesium sulphate $\left(\mathrm{MgSO}_{4} .7 \mathrm{H}_{2} \mathrm{O}\right)=0.5 \mathrm{~g}$ Ferrous sulphate $\left(\mathrm{FeSO}_{4} .7 \mathrm{H}_{2} \mathrm{O}\right)=0.19 \mathrm{~g}$, Sucrose $\left(\mathrm{C}_{12} \mathrm{H}_{22} \mathrm{O}_{11}\right)=30 \mathrm{~g}$ Agar-agar $=15 \mathrm{~g}$

Distilled water $=1000 \mathrm{ml}$

Elliot's Agar (EA)

Sodium carbonate $\left(\mathrm{Na}_{2} \mathrm{CO}_{3}\right)=1.05 \mathrm{~g}$

Magnesium sulphate $\left(\mathrm{MgSO}_{4} .7 \mathrm{H}_{2} \mathrm{O}\right)=0.60 \mathrm{~g}$ Asparagine $=3.00 \mathrm{~g}$

Dextrose $\left(\mathrm{C}_{6} \mathrm{H}_{12} \mathrm{O}_{6}\right)=3.00 \mathrm{~g}$

Potassium dihydrogen orthophosphate $=1.36$ $\mathrm{g}\left(\mathrm{KH}_{2} \mathrm{PO}_{4}\right)$

Agar-agar $=20.00 \mathrm{~g}$

Distilled water $=1000 \mathrm{ml}$

\section{Sabouround's agar}

Dextrose $=200 \mathrm{~g}$

Peptone $=20 \mathrm{~g}$

Agar-agar $=20 \mathrm{~g}$

Distilled water $=1000 \mathrm{ml}$

\section{Results and Discussion}

The results obtained from the present investigation are summarized below: 
Table.1 Effect of different cultural media on colony diameter, growth characters and Sclerotia formation of S. rolfsii Sacc. causing root rot of chilli

\begin{tabular}{|c|c|c|c|c|}
\hline $\begin{array}{l}\text { Tr. } \\
\text { No. }\end{array}$ & Media & $\begin{array}{l}\text { Average colony } \\
\text { diameter }(\mathrm{cm})^{*} \\
10 \text { days after } \\
\text { Inoculation }\end{array}$ & Growth characters & Growth \\
\hline 1 & $\begin{array}{l}\text { Potato dextrose } \\
\text { agar }\end{array}$ & 9.0 & Mycelium milky white, flat thick mycellial growth with good sclerotia formation & ++++ \\
\hline 2 & $\begin{array}{l}\text { Host extract } \\
\text { agar(Chilli) }\end{array}$ & 9.0 & Mycelium milky white, flat thick growth and dark sclerotia were formed & ++++ \\
\hline 3 & Oat meal agar & 8.0 & Mycelium is milky white, fluffy and sclerotia formed & +++ \\
\hline 4 & Carrot agar & 7.1 & White thick mycelium. sclerotia were formed. & +++ \\
\hline 5 & Plane agar & 4.2 & White pale and thin mycelium.no sclerotia formation & - \\
\hline 6 & Richards agar & 7.5 & Milky white mycelim with uniform margin .dark,small sclerotia were formed. & +++ \\
\hline 7 & Czapeks agar & 6.1 & White mycelium with flat round growth. sclerotia were formed & ++ \\
\hline 8 & Elliots agar & 2.2 & White mycelium with uneven topography. Sclerotia were lately formed & + \\
\hline \multirow[t]{3}{*}{9} & Saboround's agar & 8.2 & White thick fluffy mycelium. Sclerotia formed & +++ \\
\hline & S.E. \pm & 0.09 & & \\
\hline & C.D. at $5 \%$ & 0.26 & & \\
\hline
\end{tabular}




\section{Plate.1 Effect of different cultural media on growth of Sclerotium rolfsii}

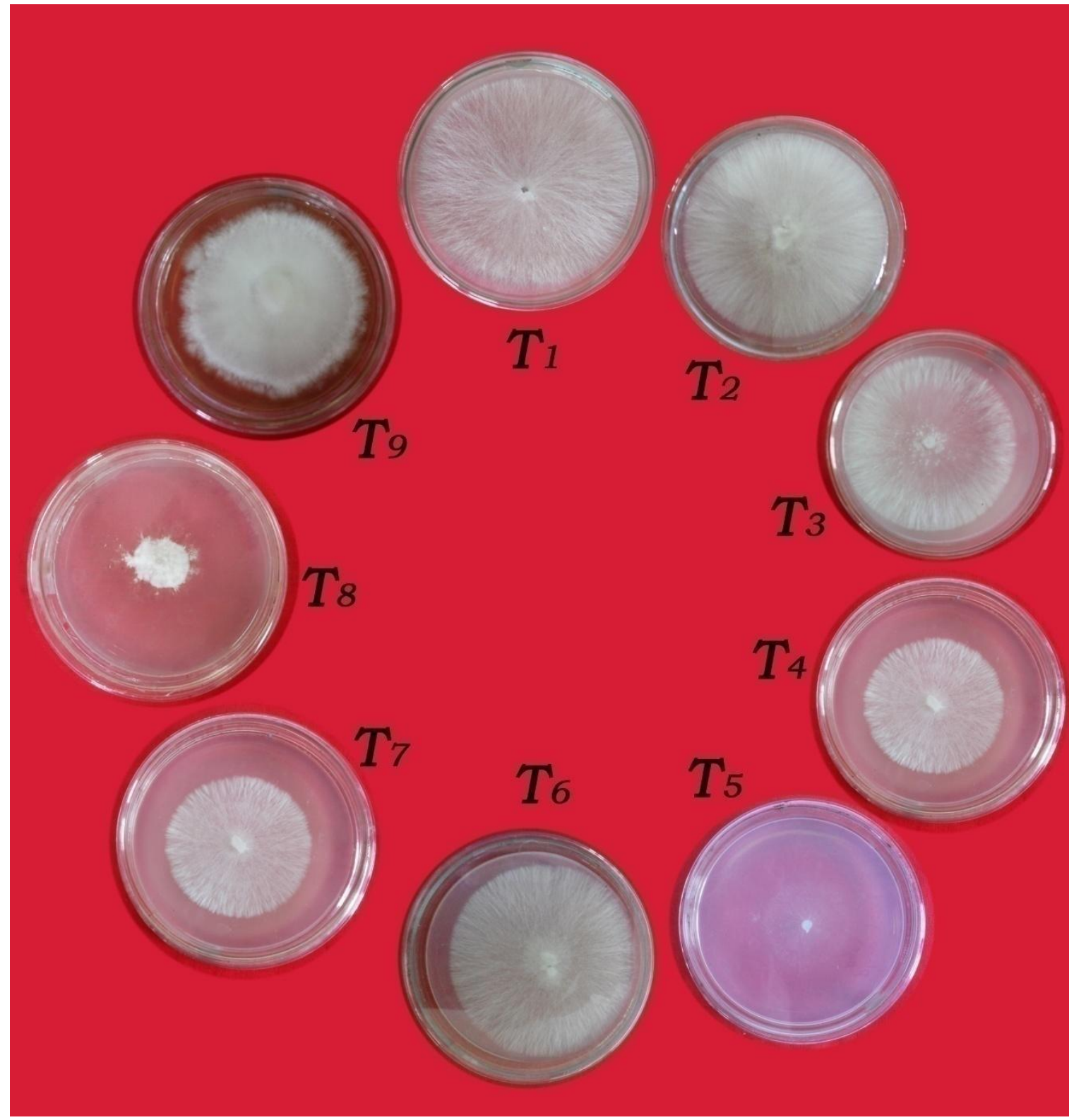

$\mathrm{T}_{1}$ Potato dextrose agar

$\mathrm{T}_{2}$ Host extract agar

$\mathrm{T}_{3}$ Oat meal agar

$\mathrm{T}_{4}$ Carrot agar

$\mathrm{T}_{5}$ Plane agar
$\mathrm{T}_{6}$ Richard's agar

$\mathrm{T}_{7}$ Czapek's agar

$\mathrm{T}_{8}$ Elliot's agar

$\mathrm{T}_{9}$ Saboround's agar
Effect of different cultural media on growth of $S$. rolfsii. Sacc

Cultural characters of the test fungus were studied on nine different synthetic and semisynthetic media. After seven days of inoculation, the treatment differences in respect of colony diameter, growth characteristics and sclerotia formation were noticed, which are presented in Table 1 and Plate-1. 


\section{Growth}

The result presented in Table 1 revealed that the maximum growth was recorded on Potato dextrose and host extract agar medium with milky white, flat thick mycellial growth with colony diameter of $9.0 \mathrm{~cm}$ followed by Saboroud's agar medium with colony diameter $8.2 \mathrm{~cm}$ which produced white thick fluffy mycelium.

The next best treatments were Oat meal 8.0 cm with milky white fluffy colony, Richard's agar media has of $7.5 \mathrm{~cm}$ with aerial milky white mycelium with uniform margin followed by, Carrot agar with $7.1 \mathrm{~cm}$ with white thick mycelium, Czapek's Dox agar 6.1 $\mathrm{cm}$ with circular flat white mycelium, Plane agar medium $4.2 \mathrm{~cm}$ colony diameter with pale thin growth of mycelium and Elliot's agar $2.2 \mathrm{~cm}$ produced white mycelium with uneven topography.

In conclusion, cultural characters of fungus were studied on nine solid media. The excellent growth and sclerotia formation was observed on Potato dextrose agar and Host extract agar medium (Chilli) followed by Saboroud's agar, Oat meal and Richards' agar. The colony of Sclerotium rolfsii was circular, white with thick growth on the upper surface of PDA.

\section{References}

Abeygunawardana, D.V.W. and R.K.S. Wood. 1957. Factors affecting germination and mycelia growth of Sclerotium rolfsii Sacc. Trans. Brit. Mycol. Soc., 40: 221-231.

Aycock, R. 1966. Stem rot and other diseases caused by Sclerotium rolfsii. N.C. Agric. Exp. Stn. Tech. Bull. 174: 202.

Basamma, Keshav Naik., C. Madhura and L.M Anjunath 2012. Cultural and physiological studies on Sclerotium rolfsii causing sclerotium wilt of potato. International Journal of Plant Science. 7 (2) 216-219.

Rupe, J. C. 1999. Sclerotium blights. In: Compendium of Soybean Diseases. $4^{\text {th }}$ ed. Hartman G. L., Sinclair J. B. and Rupe J. C., APS Press, The American Phytopathological Society. 100.

Aken, C. N. and Dashiell, K. E. 1991. First report of southern blight caused by Sclerotium rolfsii on soybean in Nigeria. Plant Dis. 75: 537.

Endo, S. 1935. Influence of $\mathrm{H}^{+}$ion concentration on the mycelial growth of causal fungi of sclerotial disease of rice. Plant Bull. Miyazaki. 8(1):11.

Gawande, M., Bagyaraj, J., Sirsi. 2013. Studies on oxalic acid synthesis by Sclerotium rolfsii Sacc. Current Sciences. 34(7): 458-459.

Grover, R.K. and B.L. Chona. 1960. Comparative studies on Sclerotium rolfsii Sacc. and Ozonium taxanus Neal. and Wester var. parasiticum. Indian phytopath. 13(4): 118-129.

Hussain Azhar, Iqbal Muhammad, Majid Abdul. 2003. Physiological study of Sclerotium rolfsii Sacc. Pakistan Journal of plant pathology. 2(2):102106.

Indramani Bhagat. 2011. Factors influencing mycelia growth of Sclerotium rolfsii. Sacc. Journal of Biosciences. 1: 26-31.

Misra, A.P. and Haque, S. Q. 1962. Factors affecting the growth and sclerotial production in Sclerotium rolfsii causing storage rot of potato. proc. Ind. Acad. Sci. Sect. B. 56(3):157-168.

Muthukumar and Venkadesh. 2013. Physiological studies on Sclerotim rolfsii Sacc. causing collar rot of peppermint. African Journal of Biotechnology. 12(49): 6837-6842.

Patil, B.G. 1963. Studies on isolation, Pathogenicity and Physiology of Sclerotium rolfsii Sacc. Causing wilt of 
groundnut. Thesis M.Sc. (Agri.) submitted to university of Nagpur.

Reddi Kumar, Madhavi santhoshi, T. Giridhara Krishna and K. Raja Reddy. 2014. Cultural and Morphological Variability Sclerotium rolfsii isolates infecting Groundnut and its relation to some fungicides. International Journal of current Microbiology and Applied Sciences. 3(10): 553-561.

Ronak Kumar and Sumanbhai, M. 2015. Cultural and physiological studies on Sclerotium rolfsii causing scleotium wilt of potato. International Journal of Plant Sciences. 7(2): 216-218.

Shridha Chaurasia, Kumar Amit., Shubha Chaurasia and Sushmita Chaurasia. 2014. Pathological Studies of
Sclerotium rolfsii causing Foot rot disease of Brinjal (Solanum melongena Linn.). International journal of pharmacy and life sciences. 5(1): 32573264.

Sumia Fatima and Uzma Quadri. 2015. The effect of different media on radial growth of Sclerotium rolfsii causing chilli root rot. Trends in life sciences. 4(4): 778-780.

Takahashi, T. 1927. A Sclerotium disease of Larkspur. Phytopathology, 17(3):239244.

Zamir K. Punja. 1895. The Biology, Ecology and Control of Sclerotium rolfsii Sacc. Ann. Rev Phytopathology. 23(2):97127.

\section{How to cite this article:}

Archana, T.S., Pankaj B. Deore, S.D. Jagtap and Patil, B.S. 2019. Effect of Different Cultural Media on Growth of Sclerotium rolfsii sacc. causing Root Rot of Chilli. Int.J.Curr.Microbiol.App.Sci. 8(02): 3019-3024. doi: https://doi.org/10.20546/ijcmas.2019.802.353 